died during such tests. This vector was administered to about 20 individuals during the Gelsinger trial, most of whom-except for Gelsinger-developed a range of moderately adverse symptoms.

Other factors appear to complicate the clinical use of adenovirus-based gene vectors, according to Wilson and other researchers. For instance, the doses at which there are toxic effects or potential therapeutic effects may be separated only narrowly, and there may be thresholds where adverse effects abruptly appear-complicating how vectors might be used and perhaps undermining the reliability of results from tests in animals. Moreover, such viruses can sometimes provoke or otherwise disrupt cytokine-determined inflammatory responses, according to Linda Gooding of Emory University (Atlanta, GA), one of several experts on a NIH-FDA working group that is reviewing adenovirus-related adverse effects.

Equally if not more problematic for would-be gene-therapy procedures, these vectors are not so reliable in delivering genes to where they are targeted. After the adenovirus vector was applied through a catheter onto the liver of Gelsinger and others in the trial, it spread widely through other organs and also, at least early on, into immune system cells, based on the post mortem analysis of his tissues-distributing quite differently from how it behaved during animal experiments, according to Wilson.

FDA officials routinely review genetransfer and gene-therapy proposals, which are also subject to oversight by officials in the NIH Office of Biotechnology Activities (OBA; formerly, Office of Recombinant DNA Activities). In the aftermath of the Gelsinger death, FDA officials began a formal investigation of the UP clinical trial. Kathryn Zoon, Director of the FDA Center for Biologics Evaluation and Research, said there was "preliminary evidence of protocol deviations." Although Zoon would not describe these violations, they apparently concern escalating doses and enrolment of patients. For instance, the slot that Gelsinger filled was originally for a woman, according to the protocol. Another apparent violation revolves around ammonia levels in Gelsinger's blood, which were higher than those stipulated by the protocol.

However, other agency officials indicated that there was extensive communication between them and members of the UP team during the course of the clinical trial. Moreover, on several occasions, officials explicitly approved requests from the UP team to move ahead and use higher doses of the adenovirus vector-the highest of which proved fatal in Gelsinger's case.

In addition to the specific investigation, FDA and NIH officials renewed their gene therapy review-harmonizing efforts, and both agencies notified researchers in this field of their obligations to report adverse effects promptly. The proposals embedded in these formal notices led industry representatives to renew long-held objections to the duplicative regulatory hoops through which researchers in this field need to jump. For example, the Biotechnology Industry Organization (BIO; Washington, DC) issued a white paper in December urging NIHRAC, OBA, and FDA to protect information furnished to them and, in particular, avoid disclosing proprietary information. It also admonished officials to keep FDA "the only agency with regulatory authority," while maintaining NIHRAC in its "role as an educational advisory body."

Jeffrey L. Fox

\title{
MAG's demise signals trouble for bioinformatics firms
}

In contrast to the vigor of public companies like CuraGen, Celera, and Affymetrix, whose share prices are currently appreciating rapidly, smaller private companies that serve the genomics sector appear to be on shakier footing. The demise in December of Molecular Applications Group (MAG), a bioinformatics software company in Palo Alto, CA, could portend trouble ahead for other specialty firms.

Debbie Yu, a Silicon Valley venture capitalist and MAG's caretaker president, who broke up the company and sold off its parts to Affymetrix (Santa Clara, CA) and Celera (Rockville, MD), says, "bioinformatics software can still be an attractive business, but the tools have to be really effective and valueenhancing." She says that many of the companies' problems are due to both what they sell and how they sell it.

These companies face the especially-formidable twin hurdles of narrow markets and high development costs. Cordell Brown, General Manager of Hitachi Genetic Systems (Alameda, CA), whose DNASIS suite of sequence analysis programs were a mainstay of the company until the mid-90s, says his company's emphasis today has shifted to equipment such as chip spotters and fluorescence

Potter Wickware is a freelance writer working in Mill Valley, CA. imagers. Market saturation plus competition from the NCBI's (US National Center for Biotechnology Information) free tools and databases equaled an environment in which "we couldn't make it on software alone."

Roy Whitfield, president of Incyte Pharmaceuticals in Palo Alto, CA, concurs. "Even if specialty companies do everything right and dominate the field, the numbers aren't there," he says, citing chemical informatics. In that sector, a couple of dozen companies a decade ago, such as BioCAD and Hypercube, have today sifted down to two dominant firms-MDL Information (San Leandro, CA) and Molecular Simulations (San Diego, CA).

It is the financiers of the first generation of bioinformatics companies who are to blame, according to Lion Bioscience's (Heidelburg) Christian Marcazzo, product manager for its SRS bioinformatics databasequerying software. They "grievously underestimated the scientific and technological hurdles necessary to bring these products to market." Marcazzo says that from concept to product to IPO in 15 months-as if they were e-commerce companies- "is not a realistic expectation in bioinformatics, as the venture capitalists are now discovering."

Companies like MAG also hurt themselves with inappropriate marketing strategies, adds Yu. "Software is too often sold under license agreements, but unless these are at least 6 figures, it's a long row to hoe to get to a big enough revenue base." Pharma customers don't like buying expensive software solutions, she continues, so a modular approach such as the creative one Spotfire (Cambridge, MA) has adopted is a better business model for specialty companies. "Spotfire is maximizing every possible distribution channel," she observes.

Meanwhile, Whitfield believes that content provision and data processing have far more potential for growth and revenue, and are thus more interesting from a business standpoint, than the tools segment. "Content, data processing, and tools are three quite different businesses, and have different sustainabilities," he says.

Doug Brutlag, a Stanford biochemistry professor and chief scientific officer of DoubleTwist (Oakland, CA), says the internet is one way for small bioinformatics companies to broaden their base. "The old paradigm of software and database distribution to the customer is on the decline, and the modern one of providing services on the Web, so that the customer comes to you, is taking over," he says. DoubleTwist, which provides application services for gene discovery, is in the process of reinventing itself along these lines. "Each scientist has different needs, and software may be low on the list."

Potter Wickware 